\title{
IDEOLOGI FEMINISME DALAM NOVEL ZEINA KARYA NAWAL EL SAADAWI BERDASARKAN PERSPEKTIF STRUKTURALISME GENETIK LUCIUS GOLDMANN
}

\author{
Abdul Basid dan Isma Nida Aulia \\ Fakultas Humaniora, UIN Maulana Malik Ibrahim Malang \\ email: abdulbasid@bsa.uin-malang.ac.id; nidaaisma@gmail.com
}

\begin{abstract}
ABSTRAK
Tulisan ini bertujuan untuk menguraikan Ideologi Feminisme dalam Novel Zeina karya Nawal El Saadawi. Peneliti menggunakan perspektif Strukturalisme Genetik yang meliputi fakta kemanusiaan, subjek kolektif, pandangan dunia, strukturasi karya sastra dan metode dialektika pemahaman penjelasan sebagai alat analisis. Hasil penelitian ini adalah a) fakta-fakta kemanusiaan baik yang bersifat individual seperti kondisi psikologis tokoh utama laki-laki yang mengalami kelainan seksual sehingga berdampak terhadap adanya frigiditas terhadap wanita, marginalisasi, subordinasi dan eksploitasi jasmaniah, maupun yang bersifat sosial seperti masyarakat patriarki; b) Subjek kolektif tokoh sentral wanita dalam novel mewakili wanita terhormat dari kalangan atas yang terstrukturasi dengan relasi yang terjadi baik antar tokoh, antara tokoh laki-laki dan tokoh perempuan maupun tokoh sentral dengan dunianya yang berlatar negara Mesir; c) Pandangan dunia pengarang yang ditemukan adalah adanya ideologi feminisme liberal dan radikal; d)strukturasi karya sastra nampak dalam merepresentasikan tokoh wanita yang termarginalkan dan hubungannya dengan kaum laki-laki yang mendominasi; dan e) dialektika pemahaman nampak dalam penggambaran budaya patriarki yang berkembang dalam masyarakat arab menjadikan laki-laki sebagai pemegang sentral kekuasaan dan wanita menjadi kelompok yang tersubordinasi. Hal ini yang menjadikan Nawal El Saadawi menuntut kesetaraan gender dengan cara menanamkan ideologi feminisme dalam setiap karya-karyanya.
\end{abstract}

Kata Kunci: ideologi feminisme, fakta kemanusiaan, subjek kolektif, pandangan dunia, strukturasi karya sastra

\section{FEMINISM IDEOLOGY IN ZEINA BY NAWAL EL SAADAWI BASED ON GENETIC STRUCTURALISM PERSPECTIVE BY LUCIUS GOLDMANN}

\begin{abstract}
This paper aims to describe the ideology of feminism in the novel Zeina by Nawal El Saadawi. Researchers use Genetic Structuralism's perspective which contains the facts of humanity, collective subjects, worldviews, the structure of literary, and the dialectical method of understanding explanations as analysis tool. Results of this study are a) the facts of humanity expresses individual facts of humanity, such as the psychological condition of the male main character who is experiencing sexual disorder, which affects frigidity, discrimination and bodily exploitation towards women, and also social facts of humanity such as patriarchal society; b) collective subject represents the respectable women of the upper circle who are structured with relationships that occur between the characters, between male and female figures as well as central figures with his world setting in the country of Egypt; c) worldview elaborates the ideology of liberal and radical feminism; d) the structure of literaryreflected in the participation of women in the public sphere is still relatively low because it is dominated by men; and e) the dialectical method of understanding explanations shows that a man is stronger and has a full sthrength than a women Arabic society. Thus, it causes Nawal El Saadawi demand gender equivalent through her literature works.
\end{abstract}

Keywords: feminism ideology, the facts of humanity, collective subject, worldview, the structure of literary 


\section{PENDAHULUAN}

Keberadaan karya sastra tidak dapat dipisahkan dari pandangan dunia pengarang karena karya sastra adalah hasil dari percampuran antara pengalaman, imajinasi, pemikiran, refleksi wawasan dan rekaman budaya pengarang terhadap sesuatu yang terjadi dalam dirinya sendiri dan masyarakat yang melingkupinya. Dalam sebuah karya sastra pengarang menstrukturasikan pandangan dunianya ke dalam sebuah cerita melalui seperangkat gagasan yang disebut dengan ideologi. Pandangan dunia pengarang ini dapat tercermin dari ideologi tokoh-tokoh dalam sebuah karya sastra novel.

Ideologi secara umum adalah (1) kumpulan konsep bersistem yang dijadikan asas pendapat (kejadian) yang memberikan arah dan tujuan untuk kelangsungan hidup; (2) cara berfikir suatu golongan; (3) paham teori dan tujuan yang berpadu merupakan satu program politik (Departemen Pendidikan Nasional, 1982: 320).

Karya sastra merupakan pandangan dari perilaku atau aktivitas yang dilakukan oleh subjek kolektif. Aspirasi pengarang adalah aspirasi yang mewakili kolektifitas kelompok sosialnya. Kedudukan sosial pengarang dalam kelompok sosialnya kemudian menjadi penting dan memengaruhi karya sastra yang ditulisnya.

Ideologi merupakan suatu sistem nilai atau kepercayaan yang diterima sebagai fakta atau kebenaran oleh kelompok tertentu. Ideologi terdiri dari rangkaian sikap terhadap berbagai lembaga dan proses kemasyarakatan. Ideologi memberi orang-orang yang percaya suatu gambaran tentang dunia baik sebagaimana adanya maupun sebagaimana seharusnya dan ia juga mengatur kompleksitas dunia sampai ke sesuatu yang agak sederhana dan dapat dipahami (Mannheim,1991: 3).

Karl Marx menyatakan bahwa setiap rangkaian khayalan politis yang telah dihasilkan oleh pengalaman sosial suatu kelas sebagai sebuah ideologi. Bagi Marx, keanggotaan seseorang dalam kelas tertentu menghasilkan suatu gambaran dunia yang dibentuk oleh pengalaman-pengalaman kelas itu (Mannheim,1991: 4). Sigmund Freud melihat ideologi sebagai khayalan yang membuat kita tertipu dan sarat dengan kondisi yang sulit jika tidak amat berat (Mannheim, 1991: 6).

Istilah ideologi, memiliki sejarah yang panjang dan kompleks, yang tampak dalam karya beberapa penulis. Di satu sisi, 'ideologi' digunakan oleh beberapa penulis sebagai 'sistem berpikir', 'sistem kepercayaan', 'praktik-praktik simbolik' yang berhubungan dengan tindakan sosial(Thompson, 2007: 17). Ideologi diperkaya dan dielaborasi melalui sebuah refleksi bahasa. Karena itu segera disadari bahwa ide-ide tidak hanya beredar di dunia sosial, tapi lebih dari itu, ide-ide berputar dalam dunia sosial sebagai ucapan-ucapan, ekspresi, sebagai kata-kata yang berbicara atau mengesankan (Thompson, 2007: 14). Ideologi membuat kita melihat bahwa bahasa bukan sekedar struktur yang dapat digunakan untuk komunikasi dan pertunjukan, tapi sebagai fenomena sejarah sosial yang melibatkan konflik manusia(Thompson, 2007: 15).

Sebagai contoh ideologi yang muncul di sekitar kita khususnya dalam sebuah karya sastra adalah lahirnya para penulis yang memperjuangkan kedudukan perempuan dalam karya sastra mereka. Perempuan yang menjadi tokoh utama dalam karya sastra tersebut digambarkan sebagai perempuan yang berani, tangguh dan memiliki sifat-sifat dan kedudukan yang sama seperti laki-laki. Melalui karya sastra seperti inilah paham ideologi kesetaraan gender tersebar.

Novel Zeina karya Nawal El Saadawi adalah novel yang sarat dengan fenomenafenomena sosial yang kompleks. Novel ini menceritakan tentang kehidupan Bodour, seorang kritikus sastra dan professor Universitas terkenal di Mesir yang memiliki masa lalu yang kelam ketika dia menjadi mahasiswi dan jatuh cinta pada seorang aktivis politik hingga melahirkan seorang anak diluar pernikahan yang diberi nama Zeina.

Permasalahan muncul ketika Bodour membuang Zeina di jalanan Kairo. Adapun iamemulai kehidupan barunya menjalani pernikahan tanpa cinta dengan seorang jurnalis terkenal. Dibalik kegemilangan karir dan keluarganya, Bodour menerima kekerasan dari suaminya, tertekan dengan bayang-bayang masa lalu dan menanggung kerinduannya terhadap Zeina. Seluruh keluh kesahnya hanya mampu ia 
tuangkan dalam cerita fiksi yang ia tulis selama hidupnya. Namun saat novel itu hilang, Bodour terpaksa harus berjuang menghidupkan masa lalu dan masa depannya. Novel ini memberikan gambaran pada kita tentang ideologi wanita Mesir dan kondisi sosial yang melatarinya pada masa itu.

Fenomena ideologi feminisme dalam novel ini akan sangat menarik jika diteliti dengan perspektif Strukturalisme Genetik Lucius Goldmann. Teori strukturalisme genetik Lucius Goldmann adalahcabang penelitian sastra secara struktural yang tidak murni. Hal ini merupakan penggabungan antara konvergensi penelitian struktural dengan penelitian yang memperhatikan aspek-aspek eksternal karya sastra agar kelengkapan suatu karya sastra menjadi sempurna. Strukturalisme genetik juga disebutkan sebagai sebuah struktur yang terdiri dari perangkat kategori yang saling berkaitan satu sama lain.Goldmann menyebut teorinya sebagai strukturalisme genetik karena ia percaya bahwa karya sastra itu merupakan sebuah struktur. Akan tetapi, struktur itu bukanlah sesuatu yang statis, melainkan merupakan produk dari proses sejarah yang terus berlangsung dan dihayati oleh kalangan masyarakat yang bersangkutan (Edraswara, 2003: 55).

Strukturalisme genetik sendiri diartikan sebagai salah satu teori yang pernyataannya dianggap benar mengenai suatu kenyataan yang didalamnya terkandung gambaran tentang tata kehidupan yang padu. Adapun konsep-konsep yang mendasari teori strukturalisme genetik ada 5, yaitu: fakta kemanusiaan, subjek kolektif, strukturasi karya sastra, pandangan dunia dan dialektik pemahaman-penjelasan(Faruk,2016: 57).

Secara definitif strukturalisme genetik adalah analisis struktur dengan memberikan perhatian terhadap asal-usul karya (Ratna, 2013: 193). Asal usul atau genetika disini adalah yang berkaitan dengan kondisi sosial, ekonomi, politik dan budaya tempat karya sastra tersebut dilahirkan. Peranan pengarang sebagai subyek yang melihat suasana sosial, politik, ekonomi dan budaya menjadi sangat penting. Sehingga Pengarang dipandang sebagai subjek yang memiliki kompetensi yang paling memadai da- lam menghasilkan sebuah karya sastra (Ratna, 2013: 194).

Menurut Goldman pendekatan ini memandang sebuah karya sastra dari struktur, pandangan sosial kelompok pengarang, dan kondisi eksternal pengarang untuk menemukan world vision atau world view atau pandangan dunia (Edraswara, 2003: 57). Pandangan dunia disini menjadi fokus dalam penelitian ini. Hal ini peneliti lakukan untuk melihat sejauhmana pandangan dunia pengarang tertuang dalam dalam terkait dengan obyek yang dilihatnya. Adapun novel Zeina yang sebagaimana peneliti angkat diatas sangat sesuai untuk dikaji dengan menggunakan teori tersebut.

Novel Zeina pada hakekatnya adalah menggambarkan kenyataan sosial kehidupan wanita dan perlakuan masyarakat pada kaum wanita pada waktu itu, sehingga hal inilah yang mendasari peneliti untuk memilih novel tersebut. Dalam novel Zeina terdapat pandangan Nawal El Saadawi terhadap kaum perempuan dan masyarakat yang melingkupinya. Masalahmasalah sosial yang terjadi terhadap Bodour menjadikan Bodour harus bangkit di tengah keterpurukannya menghadapi perlakuan tidak semena-mena yang dilakukan suaminya, Zakaria dan keluarganya.

Nawal El Saadawi mengangkat cerita tentang masyarakat kelas atas untuk menggambarkan keadaan realitas sosial masyarakat yang diamatinya dengan segala problem sosialnya. Nawal El Saadawi seakan ingin menyuarakan aspirasinya terhadap kondisi sosial wanita mesir waktu itu lewat novelnya. Ahirnya gambarangambaran yang ditampilkan oleh Nawal El Saadawi melalui Novel Zeina ini sangatlah menarik berdasarkan latar belakang sosial yang ada dalam novel tersebut.

Penelitian terhadap novel Zeina dengan pendekatan Sosiologi sastra teori strukturalisme Lucian Goldman ini sangat menarik untuk dilakukan, karena gambaran-gambaran dalam novel tersebut adalah menggambarkan kenyataan yang terjadi ketika novel tersebut dilahirkan sesuai yang diungkapkan peneliti diatas. Secara detail, penelitian ini bertujuan untuk mengungkap beberapa hal, yaitu: a) fakta-fakta kemanusiaan yang melatarbelakangi kemunculan ideologi feminisme dalam novel Zeina karya 
Nawal Al Saadawi; b) subjek kolektif pengarang terhadap ideologi feminisme tokoh dalam novel Zeina karya Nawal Al Saadawi; c) strukturasi sosial dalam novel Zeina karya Nawal Al Saadawi; d) pandangan dunia pengarang yang terdapat dalam novel Zeina karya Nawal Al Saadawi; dan e) dialektika keseluruhan-bagian dan penjelasan-pemahaman yang ada dalam novel Zeina karya Nawal Al Saadawi.

\section{METODE}

Jenis penelitian ini adalah penelitian kualitatif, yaitu metode penelitian yang berlandaskan pada filsafat postpositivisme, digunakan untuk meneliti pada kondisi obyek yang alamiah, dimana penelitiadalah sebagai instrumen kunci (Sugiyono, 2015: 9). Berdasarkan sifatnya, penelitian ini juga disebut sebagai penelitian deskriptif karena melakukan penggambaran secara mendalam tentang situasi atau proses yang diteliti, yaitu menjelaskan fenomenafenomena berupa teks dan simbol-simbol yang terkandung dalam novel Zeina karya Nawal El Saadawi (Idrus, 2012: 24).

Sumber data primer adalah sumber data yang langsung memberikan data kepada pengumpul data (Sugiyono, 2015: 225). Adapun sumber data primer dalam penelitan ini adalah novel terjemahan Zeina karya Nawal El Saadawi yang novel aslinya diterbitkan oleh Dar Al Saqi Mesir pada tahun 2009 lalu diterjemahkan ke dalam bahasa Indonesia dengan judul yang sama oleh Muasomah dan diterbitkan oleh Mitra Pustaka Yogyakarta pada tahun 2014.

Teknik pengumpulan data yang digunakan dalam penelitian ini adalah teknik baca dan catat. Dalam proses pengumpulan data tersebut, tugas utama peneliti adalah membaca dan mencatat informasi yang terkandung dalam data (Kaelan, 2012: 163).Menurut Wilson, membaca pada prinsipnya memiliki tujuan utama untuk mencari keterangan-keterangan yang berkaitan dengan data penelitian. Selain itu,membaca juga akan memberikan keluasan pandangan, terutama dalam hubungannya dengan objek formal penelitian (Kaelan, 2012: 163).Secara garis besar, teknik membaca terbagi menjadi dua, yaitu teknik membaca scanning dan skimming (Rahim, 2005: 35). Sedangkan mencatat adalah proses perekaman dan pencatatan data pada kartu-kartu data secara sistematis dan terorganisir dengan baik, agar memudahkan pemantauan jalan penelitian. Pencatatan bisa dilakukan dengan empat cara; 1) mencatat data secara quotasi, 2) mencatat data secara parafrase, 2) mencatat secara sinoptik, 3) mencatat secara pengkodean, 4) mencatat secara précis (Kaelan, 2012: 167-168).

Untuk mendapatkan data yang valid dan kredibel, peneliti melakukan uji credibility (validitas internal) terhadap data yang sudah peneliti dapatkan. Uji kredibilitas ini terdiri dari 3 langkah, yaitu meningkatkan ketekunan, triangulasi (triangulasi sumber, triangulasi teknik dan triangulasi waktu) (Sugiyono, 2015: 270-274), dan diskusi dengan ahli atau teman sejawat (Moleong, 2012: 331).

Adapun metode analisis data yang digunakan dalam penelitian ini adalah metode model Miles dan Hubermann. Menurut Huberman yang terdiri dari empat langkah, yaitu: data collection (pengumpulan data), data reduction (reduksi data), data display (penyajian data), conclusion drawing (penarikan atau verifikasi kesimpulan) (Huberman, 1994: 30).

\section{HASIL DAN PEMBAHASAN Fakta Kemanusiaan}

Adapun fakta-fakta kemanusiaan yang telah diketahui dalam kajian teori terdiri dari fakta kemanusiaan yang bersifat sosial dan individual. Semua unsur yang mendukung aktivitas yang menjadi fakta kemanusiaan itu terarah kepada tercapainya tujuan yang dimaksud dalam hal ini adalah ideologi feminisme. Adapun tujuan yang menjadi arti dari faktafakta kemanusiaan itu sendiri tumbuh sebagai respon dari subjek kolektif ataupun individual terhadap situasi dan kondisi yang ada di dalam diri dan sekitarnya. Dalam novel ini terdapat beberapa fakta kemanusiaan baik yang bersifat sosial maupun individual yang melatarbelakangi terbentuknya ideologi feminisme.

Adapun fakta kemanusiaan yang muncul pada permulaan cerita adalah tokoh Aku dalam novel yaitu Mageeda Al Khartiti yang merupakan anak dari Zakaria Al Khartiti dan Bodour Ad Damhiri yaitu seorang dari keturunan keluarga terhormat. Dalam kehidupan sehari-harinya, Mageeda seringkali menda- 
pati ayahnya -yang merupakan tokoh laki-laki sentral dalam cerita- menyiksa ibunya dengan melakukan kekerasan-kekerasan. Hal tersebut tergambar dalam kutipan berikut:

Ketika umurku mencapai lima belas tahun, aku mulai mengerti sesuatu yang tersembunyi dalam hubungan ayah dan ibuku. Aku mendengar mereka berdua bertengkar pada malam hari. Suara mereka terdengar rendah, tercekat dan pelan. Pertengkaran mereka berangsurangsur semakin dahsyat. Kadang disertai dengan suara benda-benda yang jatuh ke lantai, tamparan-tamparan di wajah atau tendangan-tendangan kaki. Pukulan-pukulan itu menekan bawah tulang rusukku seiring dengan memanasnya pertengkaran (El Saadawi, 2014: 9).

Kekerasan-kekerasan yang dilakukan oleh tokoh laki-laki ini berlangsung terus menerus dan tidak mendapatkan sedikit pun perlawanan dari tokoh permpuan. Disini tampak bahwa terdapat sistem patriarki dalam keluarga dengan wanita sebagai pihak yang tersubordinasi. Hal ini tergambar dalam kutipan berikut:

Ia menarik rambut Bodour agar berteriak dan memukul pipinya dengan halus. Jika dandanannya terlalu berlebihan, ia akan menampar wajahnya, atau menyengatkan ikat pinggang kulitnya di perut dan kedua pahanya. Bodour tidak dapat membalas pukulannya dengan pukulan serupa. Kadang Zakaria bermimpi bahwa Bodour menampar wajahnya, memegang ikat pinggang kulit dan memukulinya sampai kulitnya terkelupas, sampai nafsunya yang terkubur sejak kecil dalam perutnya bangkit. Hal itu tidak terjadi kecuali dalam mimpi (El Saadawi, 2014: 93).

Dalam dirinya ada perasaan hina dan menyukai siksaan. Ia yang selalu menyiksa Bodour atau putrinya, Mageeda dipukulnya tanpa sebab atau karena sebab yang remeh. Ia ingin melampiaskan rasa marahnya, ingin menyiksa semua laki-laki yang pernah memukulnya dan semua perempuan yang pernah meno- laknya., ingin menyiksa para pemimpin negeri yang tidak pernah tersenyum padanya atau para menteri atau pimpinan redaksi. Tubuhnya penuh dengan amarah, amarah terhadap dirinya juga. Kehinaan dirinya mendorongnya dalam kekejian, kerendahan, penipuan harta dan pencurian, pemerkosaan anak-anak kecil, pergi diam-diam dari ranjang pernikahan menuju ke rumah bordil dan nafsu amarah yang buruk (El Saadawi, 2014: 93).

Kekerasan yang dilakukan oleh Zakaria Al Khartiti merupakan transformasi dari kondisi psikologisnya yang terganggu karena memiliki kelainan seksual sebagai akibat dari kejadian di masa sebelumnya. Hal tersebut dapat diketahui melalui kutipan berikut,

Di dalamnya dirinya, ia adalah seorang anak sekolahan yang melakukan pemaksaan. Kenikmatan bersetubuh terikat dalam akal dan tubuhnya dengan pemaksaan dan siksaan dari guru pertamanya yang mengambil keperjakaannya, dari ayahnya yang memukulnya dengan tongkat rotan, dari penjaga kampus, berlari di belakangnya dalam demonstrasi. Mereka memukulinya dengan tongkat besar. Ia bernyanyi seperti teman-temannya dengan sebuah ungkapan. Memukul kekasih seperti memakan kismis. Dari radio ia mengulang lagu-lagu cinta, patah hati, ratapan, penolakan dan kepergian. Cinta terikat dalam tubuhnya dan akalnya terikat dengan rasa sakit. Kecintaannya pada persetubuhan dilampiaskan dengan kekerasan dan kekejaman. Setiap kekerasan perempuan bertambah, bertambahlah pula rasa cintanya kepada perempuan itu. Ia tidak menyukai perempuan kecuali untuk meninggalkannya dan menyakitinya, membuatnya menderita, memukulnya dan berbuat kekerasan padanya sampai ia merintih di kedua tangan ibunya atau ayahnya yang kejam, atau hamba di kedua tangan Tuhan Yang Maha Besar (El Saadawi, 2014: 89). 
Dengan kata lain, Zakaria Al Khartiti memiliki kelainan seksual yang ia bawa sejak kecil sehingga ketika dewasa ia memperlakukan wanita dengan tidak wajar. Hal tersebut dapat tergambar dalam kutipan berikut:

Sesuatu di bawah perut dengan sesuatu di dalamnya menggelitiknya seiring pergerakan paha saat berjalan kaki serta gesekan daging dengan daging. Sesuatu mabuk karena sesuatu yang memabukkan, sedikit menghilangkan kenikmatan atau keinginan untuk merasakan kenikmatan. Istrinya, Bodour tidak mampu memberikan kenikmatan. Mungkin karena klitorisnya robek sejak ia kecil, disembunyikan sejak ia dilahirkan ibunya, terkekang oleh ayahnya yang seorang tentara, berubah menjadi penulis besar (El Saadawi, 2014: 81). Zakaria al-Khartiti menatap betis anak perempuan saat berjalan. Kedua matanya naik dari betis yang langsing menuju paha yang penuh dengan daging. Anak iu mengetuk tanah dengan hak sepatunya seperti kuda yang kuat. Dua mekanisme kecerdasan bingung di bawah punggungnya. Jemarinya terjulur dalam khayalannya di antara dua mekanisme tersebut, di celah yang dalam antara dua mekanisme tersebut. Keduanya berputar kuat seperti tomat. Ia tidak mengenali anak perempuan dan anak laki-laki dari belakang, anak laki-laki tumbuh di masa remajanya. Pahanya kencang seperti macan tutul. Ia dibawa oleh gurunya suatu hari ke kamar kecil, tempat ia menghilangkan kegadisan anak yatim yang tidak punya ayah dan ibu (El Saadawi, 2014: 83).

Selain itu terdapat beberapa fakta kemanusiaan yang menggambarkan adanya penindasan terhadap beberapa tokoh perempuan. Seperti adanya eksploitasi jasmaniah yang dilakukan Zakaria Al Khartiti terhadap tokoh wanita yang lainnya, Zeina. Yang tergambar dalam kutipan berikut:

Perkelahian mulai terjadi di ruang kerja itu, antara laki-laki tua yang kepalanya berisi sepertiga akalnya dan anak perempuan yang akalnya lebih besar dari umurnya. Zakaria dapat merobek baju putihnya yang terbuat dari katun Mesir dan merobek baju dalamnya, menarik betisnya menjauh dari betis satunya dan memasukkan kelaminnya diantara kedua pahanya, tetapi ia tidak mampu melakukannya. Kemaluannya yang tegak tidak mampu membuka jalan antara gundukan daging. Jalan itu tertutup, seolah di tubuhnya tidak ada celah untuk masuknya batang, seolah ia tidak memiliki kemaluan untuk masuknya kejantanan laki-laki, seolah ia bukan perempuan seperti perempuan lainnya (El Saadawi, 2014: 88).

\section{Subjek Kolektif}

Subjek kolektif terwakili oleh penulis sebagai bagian dari anggota suatu masyarakat. Adapun subjek kolektif dalam novel Zeina karya Nawal El Saadawi mewakili kelas atas dan bawah serta hubungan antara keduanya. Berikut adalah pemaparannya:

Bodour sebagai tokoh wanita sentral dalam cerita merupakan subjek kolektif dari kalangan atas yang merupakan figur wanita dari keluarga terhormat dan berpendidikan tinggi. Hal ini dapat dibuktikan dengan kutipan berikut:

Ayahku melarangku keluar ke jalanan. Ia berkata padaku bahwa anak-anak keluarga terhormat tidak bermain bersama anak-anak di jalanan. Ia mengatakan bahwa para penculik berbahaya. Surat kabar mengabarkan kejadian penculikan setiap hari. Para penjahat bertambah seiring dengan bertambahnya kemiskinan dan pengangguran. Para pemuda tamat dari universitas tanpa pekerjaan, tanpa keinginan untuk mendapatkan makanan apalagi mendapatkan istri. Mereka hidup dalam larangan dan menculik anak-anak perempuan di jalanan (El Saadawi, 2014: 7).

Sejak kecil Bodour memiliki kemasyhuran. Ia memikul kehormatan keluarga besarnya di atas bahunya, kehormatan ayahnya (El Saadawi, 2014: 12). 
Ayah Bodour melarangnya turun ke jalanan. Ia berkata bahwa anakanak jalanan adalah anak-anak zina, anak-anak iblis, khususnya anak yang pincang. Anak yang pincang seperti monyet (El Saadawi, 2014: 148).

Bodour tidak pernah keluar rumah kecuali untuk bersekolah, dalam satu langkah yang lurus, pulang pergi, tidak menoleh sana sini. Ia mendengar ayahnya berkata, "Kehormatan anak perempuan seperti batang korek api yang menyala hanya sekali. Hanya sekali. Sekali saja. Paham? (El Saadawi, 2014: 149)"

Ibunya menulis kritik sastra. Ia mengisi kuliah-kuliah di universitas tentang satra, puisi, prosa drama dan film-film bioskop. Setiap hari orang-orang mengiriminya surat secara berturut-turut mengenai buku-buku, majalah, kasetkaset musik dan fil, serta dialog sastra di radio dan $T V$ yang diperlombakan oleh para penulis untuk mendapatkan persetujuannya. Mereka mengiriminya hadiah. Dengan satu ucapan di majalah kritik sastranya, ia bisa mengeluarkan seorang penulis perempuan yang tidak dikenal dalam ketiadaan menuju cahaya dan bintang-bintang seni dan sastra (El Saadawi, 2014: 41).

Keterkaitan antara kalangan atas dan bawah terjadi ketika Bodour mencintai Nasim, teman seperjuangannya semasa kuliah yang berasal dari kalangan bawah.

Hal itu terjadi sejak beberapa tahun saat Bodour berumur dua puluh tahun yang bermimpi tentang cinta dan pemberontakan, saat ia mendapatkan gelar sarjana muda di fakultas sastra, walaupun ia tidak mencintai sastra dan juga tidak mencintai kritik sastra. Ia mencintai Nasim dan menginginkannya, memimpikannya dan tidak bias hidup jauh darinya. Ia lebih memilih hidup dengan Nasim di kamar kos daripada harus hidup bersama ayah ibunya di vila besar garden city (El Saadawi, 2014: 23)
Keterkaitan dengan kalangan bawah juga tergambar dari relasi antar tokoh perempuan, dalam hal ini relasi tokoh sentral Bodour dengan Zeina.

Zeina binti Zeinat tidak memiliki rumah dan permainan anak-anak. Ia tumbuh di jalanan, di pinggir jalan seperti pohon Tin yang berduri. Jika disentuh oleh tangan tanpa keinginannya, maka ia akan tertusuk oleh duri-durinya sampai darahnya mengalir (El Saadawi, 2014: 90).

\section{Pandangan Dunia}

Pandangan dunia merupakan kompleks menyeluruh dari gagasan-gagasan, aspirasi-aspirasi dan perasaan-perasaan yang menghubungkan secara bersama-sama anggota-anggota suatu kelompok sosial tertentu dan mempertentangkannya dengan kelompok-kelompok sosial lainnya. Adapun pandangan dunia pengarang yang muncul dalam novel Zeina adalah ideologi feminisme. Adapun ideologi feminisme yang ditemukan adalah ideologi feminisme liberal dan ideology feminisme radikal.

Feminisme liberal adalah ideologi dimana wanita memiliki kebebasan penuh karena memiliki kemampuan yang sama dengan laki-laki sehingga perempuan dan laki-laki harus diberi hak yang sama. Hal tersebut dapat ditemukan dalam tuturan-tuturan berikut:

“...Berbanggalah atas ibumu dan namamu Zeina bintti Zeinat. Nama Ibu lebih terhormat dari nama Ayah, karena Ayah hanya melepaskan lompatan benih anak-anaknya kecuali jika ia sakit jiwa atau kehilangan akalnya... (El Saadawi, 2014: 290)."

Sesungguhnya pernikahan bukanlah untuk menguasai suami, karena manusia itu bebas. Kebebasan adalah dasar moral yang paling agung, tidak ada yang menyamainya kecuali cinta (El Saadawi, 2014: 74).

Bodour tidak pernah keluar rumah kecuali untuk bersekolah, dalam satu langkah yang lurus, pulang pergi, tidak menoleh sana sini. Ia mendengar ayahnya berkata, "Kehormatan anak perem- 
puan seperti batang korek api yang menyala hanya sekali. Hanya sekali. Sekali saja. Paham? (El Saadawi, 2014: 149)."

Manusia pun mulai banyak di bumi dan melahirkan anak-anak laki-laki dan perempuan. Anak laki-laki Tuhan melihat anak perempuan manusia yang baik dan mengambil perempuan yang mereka pilih untuk diri mereka. Setelah itu jika anak Tuhan masuk ke anak manusia, mereka akan melahirkan anak-anak (El Saadawi, 2014: 196).

Allah membicarakan laki-laki dalam Al-Qur'an dan tidak membicarakan perempuan. Allah menghapus namanama perempuan dalam Al Qur'an. Ia tidak menyebutkan nama Hawa. Ia mengatakan istri Adam. Perempuan yang menggoda Nabi Yusuf namanya tidak disebut dalam Al Qur'an. Begitu juga dengan sayyidah Khadijah istri Nabi Muhammad SAW. Namanya tidak disebut dalam Al Quran secara langsung. Hanya Maryam si gadis, ibu Nabi Isa Al Masih, yang Allah sebut namanya dan memberinya kekhususan berupa surat yang sempurna dengan namanya yaitu surat Maryam (El Saadawi, 2014: 201).

Nasim mendorong Bodour untuk mengingkari Allah. Ia berkata pada Bodour, "Bagaimana bisa kau beriman pada Tuhan yang tidak membicarakanmu dan tidak menyebutkan namamu serta membuatmu sebagai pengikut suamimu? Dalam ketiga kitabNya, perempuan tidak memiliki kedudukan seperti lakilaki yang mempunyai kedudukan (El Saadawi, 2014: 201)."

"Pergilah padanya. Ia adalah perempuan seperti perempuan lainnya, kurang akal dan agama, lemah di depan nafunya. Jika seseorang lelaki memengaruhinya, maka kekuatannya hilang (El Saadawi, 2014: 276)."

"Mengapa orang-orang kristen Koptik mengakui dosa-dosa mereka kepada pendeta? Mengapa perempuan berdiri di belakang laki-laki di gereja?... Mengapa laki-laki menikahi empat perempuan dan perempuan hanya satu suami? Mengapa laki-laki memperoleh bidadari-bidadari perempuan di surga? Dan mengapa perempuan tidak memperoleh peri laki-laki? (El Saadawi, 2014: 287)"

"Mengapa surga ada di bawah telapak kaki ibu dan nama mereka membawa aib untuk anak-anak mereka? (El Saadawi, 2014: 288)"

Ibunya memandang Ahmad dengan bangga. Ia memuji Tuhan karena memberinya anak laki-laki, karena derajat laki-laki lebih tinggi daripada perempuan, seperti yang difirmankan dalam kitabNya yang agung, Ar-rijalu qawwanuna 'ala an-nisaa' bimaa anfaqu min amwalihim. Tuhan lebih mengutamakan laki-laki daripada perempuan. Inilah hikmah dan kehendaknya, perempuan kurang akal dan agama (El Saadawi, 2014: 306).

Tuhan sendiri yang mengutamakan laki-laki diatas perempuan. Maryam si gadis melahirkan Almasih dari roh Tuhan sebagai laki-laki, bukan perempuan. Ia adalah Al Masih putra Tuhan. Tuhan memperingatkan untuk berhatihati terhadap perempuan zina di dalam Injil (El Saadawi, 2014: 197).

Feminisme radikal adalah ideologi dimana perempuan merasa didominasi oleh laki-laki dan adanya ketidakadilan berdasar pada aspek biologis. Hal tersebut dapat di temukan dalam tuturan-tuturan berikut:

Perkelahian mulai terjadi di ruang kerja itu, antara laki-laki tua yang kepalanya berisi sepertiga akalnya dan anak perempuan yang akalnya lebih besar dari umurnya. Zakaria dapat merobek baju putihnya yang terbuat dari katun Mesir dan merobek baju dalamnya, menarik betisnya menjauh dari betis satunya dan memasukkan kelaminnya diantara kedua pahanya, tetapi ia tidak mampu melakukannya. Kemaluannya yang tegak tidak mampu membuka 
jalan antara gundukan daging. Jalan itu tertutup, seolah di tubuhnya tidak ada celah untuk masuknya batang, seolah ia tidak memiliki kemaluan untuk masuknya kejantanan laki-laki, seolah ia bukan perempuan seperti perempuan lainnya (El Saadawi, 2014: 88).

“....Alam semesta tidak diciptakan dalam enam hari dan perempuan tidak berasal dari tulang rusuk Adam. Bahkan Adam datang dari Rahim perempuan... (El Saadawi, 2014: 292)”

Ahmad ad-Damhiri menutup pelupuk matanya. Ia membayangkan Zeina di antara kedua lengannya. Ia melihatnya di atas tempat tidur. Ia yakin akan mendapatkan Zeina. Ia tidak menginginkan seorang perempuan kecuali untuk mendapatkannya. Tuhan memperbolehkan laki-laki untuk menjadikan perempuan sebagai budak, apalagi ia adalah seorang Amir (El Saadawi, 2014: 167).

"Musik adalah perbuatan setan, seperti menari dan menyanyi. Menyanyi adalah pekerjaan para wanita pelacur, bukan wanita terhormat...(El Saadawi, 2014: 133)"

"Perempuan adalah sekutu setan. Kebersihan adalah sebagian dari iman dan kekotoran adalah sebagian dari perempuan.. (El Saadawi, 2014: 213)"

Tidak ada yang mengotori laki-laki salih dan mukmin selain perempuan. Kebersihan sebagian dari iman dan kekotoran sebagian dari perempuan (El Saadawi, 2014: 258).

“...Menariadalah menggerakkan tubuh dengan membangkitkan nafsu. Menari tak terpisah dengan menyanyi yang juga dibenci, karena suara perempuan seperti tubuh telanjangnya. Salah satu aurat yang wajib ditutup dengan hijab, dengan perang, dengan tangan, dengan lisan atau dengan hati dan ini adalah selemah-lemahnya iman (El Saadawi, 2014: 257)."

“...Tetapi perempuan adalah makhluk yang paling buruk.” Perempuan adalah teman setan seperti yang ia dengar dari ayah dan kakeknya. Kebersihan sebagian dari iman dan kekotoran adalah bagian dari perempuan (El Saadawi, 2014: 268)."

Jika seorang lelaki menyukai bibir atau dadanya, Shofi akan menatap laki-laki tersebut dengan pandangan tajam. "Aku bukan hanya sebuah tubuh. Aku adalah otak yang berpikir. Aku adalah penulis terkenal. Sudahkah kau membaca bukuku tentang kritik sastra? Atau membaca artikelku di koran? (El Saadawi, 2014: 160)"

\section{Strukturasi Karya Sastra}

Struktur dalam karya sastra itu memiliki arti tertentu. Oleh karena itu, untuk memahami sastra sebagai produk fakta kemanusiaan harus juga mempertimbangkan struktur dan artinya. Dengan kata lain semua unsur yang membangun sebuah karya sastra itu memiliki arti dan arti dalam struktur sastra itu didasarkan pada tujuan-tujuan yang hendak dicapai. Struktur karya sastra yang diambil dalam novel Zeina adalah tokoh dan relasi antar tokoh.

Adapun mengenai strukturasi dan relasi antar tokoh dapat tergambar dari pola interaksi yang terjadi antar tokoh. Dalam hal ini Zakaria sebagai tokoh sentral laki-laki yang inferior terhadap wanita. Hal ini dapat terlihat dari perlakuannya terhadap istrinya dalam kutipan berikut:

Zakaria mengenali tawa istrinya dari ribuan tawa lainnya. Tawa panjang yang diakhiri dengan suara putusputus seperti isak yang tertahan. Zakaria tak kuasa mendengar tawa ini. Ia menampar Bodour di kamar tidur untuk menghentikan tawa tersebut. Jika Bodour menangis, Zakaria mengangkat tangannya dan menamparnya. Bodour tidak pernah mengangkat tangannya untuk membalas tamparannya. Ia menundukkan kepalanya, menyembunyikan tangis atau tawanya. Ia me nyembunyikan keinginannya untuk mengangkat tinggi tangannya dan dihujani pukulan serta tamparan di wajahnya (El Saadawi, 2014: 67). 
Adapun relasi antar tokoh dengan dunianya tergambar pada tokoh Zeina yang berkepribadian tangguh karena sejak kecil telah terbiasa dengan kehidupan jalanan. Hal ini tergambar dalam tuturan berikut:

Zeina bukan perempuan seperti layaknya perempuan di keluarganya. Ia terlatih dengan perkelahian di jalanan. Kegadisannya telah hilang sejak ia ditinggalkan ibunya di trotoar. Ia tidak lagi takut pada pencuri dan perampok. Saat itu ia berumur sembilan tahun, tetapi ia tampak seperti berumur 36 tahun (El Saadawi, 2014: 88).

Zeina binti Zeinat adalah anak yang istimewa dibandingkan dengan anakanak lainnya. Tak seorang pun dapat menyentuhnya meskipun saat ia tidur. Jemarinya yang panjang lentik seperti paku dapat ia tancapkan pada leher mana pun. Giginy merobek kulit dengan kuat dan tajam seperti pisau bedah. Taringnya keluar untuk mendapatkan sepotong daging (El Saadawi, 2014: 64).

Ia lulus dari sekolah jalanan. Ia mengetahui dasar kesedihan dan puncak kebahagiaan. Ia tidak lagi takut akan dasar dan puncak. Tak ada seorang lelaki pun yang memilikinya dan ia tidak mungkin dimiliki oleh seorang pun. Hanya musik yang memilikinya. Dia yang memiliki musik dan bebas dari kemiskinan, ketakutan dan perbudakan bersama musik (El Saadawi, 2014: 177).

"Perempuan ini membebaskan dirinya sendiri dari kepemilikan orang lain. Ia akan menjadi pemilik orang lain (El Saadawi, 2014: 297)."

Selain itu, dalam novel ini tokoh utama yang juga merupakan seorang penulis menstrukturasikan dirinya dalam novel yang ia tulis sebagai bentuk perlawanan terhadap kekerasan yang ia terima selama ini. Hal tersebut terdapat pada kutipan berikut:

Sejak di sekolah dasar, Badriyah lebih berani daripada Bodour. Ia tidak raguragu dalam mengucapkan apa yang berputar dalam otaknya (El Saadawi, 2014: 287).

...terutama Badriyah, si tokoh utama cerita. Ia adalah perempuan keras kepala dengan harga diri yang kuat. Ia tidak bertuhan, tidak memiliki pemimpin dan tak bersuami... (El Saadawi, 2014: 279)"

\section{Dialektika Pemahaman}

Pemahaman terhadap karya sastra terjadi dengan analisis terhadap unsur dan struktur yang membangun totalitas karya sastra, sedangkan penjelasan dalam analisis dengan menempatkan struktur karya sastra dalam konteks struktur yang lebih besar, yaitu struktur masyarakat. Oleh karena analisis ini bersifat dialektis, maka analisis ini bersifat bolak balik sampai mendapatkan totalitas makna atas struktur karya sastra yang berhomologi dengan struktur bermasyarakat. Adapun struktur karya sastra yang diambil dalam novel Zeina adalah homologinya dengan kondisi sosial masyarakat Revolusi Mesir pada tahun 1954. Hal ini dapat terlihat dari kondisi masyarakat yang digambarkan dalam kutipan berikut:

Sejak kecil Bodour memiliki kemasyhuran. Ia memikul kehormatan keluarga besarnya di atas bahunya, kehormatan ayahnya al-Liwa' Ahmad ad-Damhiri. Ia adalah seorang perwira tentara ketika revolusi bangkit (El Saadawi, 2014: 12).

Gelar Pasha telah jatuh seiring jatuhnya raja setelah revolusi, tetapi gelar itu kembali bersama dengan penaklukan, perserikatan asing, penutup kepala, tanda hitam di dahi, tasbih, pembesar suara di masjid-masjid, lonceng-lonceng gereja dan sekolah, peluit polisi di jalanan, selang air dan gas air mata, bertambahnya anak buangan di atas trotoar dan tempat kumuh, fatwa-fatwa syeikh dengan pemikiran para pakar, kebakaran bioskop, panggung dan gereja serta perempuan yang menuиtup kepalanya dengan hijab atau memperlihatkan perut dan pantat mereka dalam balutan jins Amerika terbaru. Begitu juga dengan kedai-kedai hamburger, 
cola diskotik, malam-malam merah di pinggir Sungai Nil, serta awan hitam yang menyelimuti kota pada siang dan malam hari (El Saadawi, 2014: 256).

Revolusi Mesir 23 Juli 1952 mengubah wajah dan arah perpolitikan. Mesir yang semula merupakan negara menggunakan sistem pemerintahan monarki parlementer, kemudian berubah menjadi republik demokrasi (Trisnawati, 2013: 4). Hal tersebut tergambar dengan kutipan-kutipan yang ada dalam novel dimana setelah revolusi Mesir pada tahun 1952 keadaan wanita-wanita Mesir masih dianggap rendah, hal tersebut ditandai dengan kalimat "bertambahnya anak buangan di atas trotoar dan tempat kumuh," yang secara implisit menunjukkan bagaimana wanita diposisikan pada saat itu.

Bahkan sampai 2 tahun pasca revolusi Mesir pada tahun 2011, kedudukan wanita Mesir masih terbilang rendah ditandai dengan maraknya kasus pengeroyokan, kekerasan seksual dan kasus pemerkosaan sedangkan pemerintah tidak memberikan tanggapan mengenai hal tersebut. Hal tersebut diungkapkan oleh Heba Morayef, direktur organisasi Human Rights Watch Mesir pada media. Seorang psikolog yang bekerja dengan para korban kekerasan seksual, Farah Shash dari Nadim Center Kairo juga ikut mengungkapkan bahwa usaha para aktivis untuk mendapatkan tanggapan dari pemerintah telah gagal karena membahas isu-isu perempuan di parlemen atau debat publik adalah bukan merupakan prioritas (Arrott, 2013).

\section{SIMPULAN}

Berdasarkan hasil penelitian diatas, dapat diambil beberapa kesimpulan sebagai berikut.

a. Fakta kemanusiaan yang terkandung dalam novel Zeina karya Nawal El Saadawi terdiri dari fakta kemanusiaan yang bersifat individual dan sosial. Fakta kemanusiaan yang bersifat individual seperti yang terjadi pada tokoh utama laki-laki Zakaria Al-Khartiti yang memiliki gangguan psikologis berupa kelainan seksual yang membuatnya semenamena memperlakukan wanita sehingga terjadi frigiditas, eksploitasi jasmaniah, pelecehan seksual yang mana hal terse- but menjadi faktor tumbuhnya ideologi feminisme yang diusung oleh tokoh-tokoh perempuan dalam novel Zeina.

b. Subjek kolektif pengarang dalam ideologi feminisme yang terkandung dalam novel Zeina adalah pengarang yang memposisikan tokoh utama wanita sebagai kalangan atas yang berpendidikan tinggi dan memiliki kehormatan dalam masyarakat. Disamping itu pengarang memposisikan tokoh-tokoh perempuan sebagai individu yang tangguh yang secara implisit merepresentasikan kegigihan pengarang dalam menyuarakan ideologi feminisme.

c. Strukturasi dalam novel Zeina karya Nawal El Saadawi secara implisit merepresentasikan tokoh wanita yang termarginalkan dan hubungannya dengan kaum laki-laki yang mendominasi.

d. Pandangan dunia pengarang dalam hubungannya dengan ideologi feminisme adalah terdapat beberapa world view pengarang yang baik secara implisit maupun eksplisit menyuarakan ideologi feminisme diantaranya adalah ideologi feminisme radikal dan ideologi feminisme liberal sebagai respon subjek kolektif terhadap fakta-fakta kemanusiaan khususnya yang berhubungan dengan posisi wanita dan perlakuan masyarakat terhadap wanita yang tertulis dalam novel.

e. Dialektika pemahaman tentang ideologi feminisme yang terdapat dalam novel Zeina merupakan pandangan seorang Nawal El Saadawi yang merupakan seorang intelektual feminis Mesir mengenai realitas masyarakat Arab. Budaya patriarki yang berkembang dalam masyarakat arab menjadikan laki-laki sebagai pemegang sentral kekuasaan dan wanita menjadi kelompok yang tersubordinasi. Kelompok wanita yang dinomorduakan oleh laki-laki menjadikan wanita mendapatkan perlakuan yang tidak layak dari laki-laki seperti eksploitasi jasmaniah, adanya marginalisasi dan diskriminasi dalam segala sektor kehidupan. Melalui karya-karyanya, Nawal El Saadawi menuntut kesetaraan gender dengan cara menanamkan ideologi feminisme dalam setiap karya-karyanya. 


\section{DAFTAR PUSTAKA}

Arrott, Elizabeth. 2011. Pasca Revolusi, Hak Perempuan Mesir Masih Terpinggirkan.04 Januari 2013. Diakses darihttps://www.voaindonesia.com/a/ pasca-revolusi-hak-perempuan-mesirmasih-terpinggirkan/1577358.html pada 07 Juli 2017 pada 20.37 WIB.

Departemen Pendidikan Nasional. 1982. Kamus Besar Bahasa Indonesia. Jakarta: Balai Pustaka.

Edraswara, Suwardi. 2003. Metode Penelitian Sastra. Yogyakarta: Media Press.

El Saadawi. 2014. Perempuan di Titik Nol. Jakarta: Yayasan Obor.

Faruk. 2016. Pengantar Sosiologi Sastra. Yogyakarta: Pustaka Pelajar.

Huberman, Matthew B Miles A Michael. 1994. Qualitative Data Analysis (Second Edition). London: Sage Publication.

Idrus, Muhammad. 2012. Metode Penelitian Ilmu Sosial Pendekatan Kualitatif dan Kuantitatif. Jakarta: Penerbit Erlangga.
Kaelan, M.S. 2012. Metode Penelitian Kualitatif Interdisipliner. Yogyakarta: Paradigma.

Mannheim, Karl. 1991. Ideologi dan Utopia; Menyingkap Kaitan Pikiran dan Politik. Yogyakarta: Kanisius.

Moleong, Lexy J. 2012. Metodologi Penelitian Kualitatif. Bandung: PT. Remaja Rosdakarya.

Muassomah. 2014. Zeina. Yogyakarta: Mitra Pustaka.

Rahim, Farida. 2005. Pengajaran Membaca di Sekolah Dasar. Jakarta: Bumi Aksara.

Ratna, Nyoman Kutna. 2013. Paradigma Sosiologi Sastra. Yogyakarta: Pustaka Pelajar.

Sugiyono. 2015. Metode Penelitian Kuantitatif, Kualitatif dan R\&D.Bandung: Alfabeta.

Thompson, John B. 2007. Analisis Ideologi. Yogyakarta: Ircisod.

Trisnawati, Diana. 2013. Revolusi Mesir 23 Juli 1952: Berakhirnya Pemerintahan Raja Farouk (Skripsi). Yogyakarta: Universitas Negeri Yogyakarta. 